\title{
Discursive resistance as a tool for servant-leaders: the tactics of Eugene V. Debs
}

\author{
Mark H. McVay \\ Whitworth University, Spokane, WA, USA
}

\begin{abstract}
With the spirit of a servant-leader, Eugene V. Debs countered the prevailing narrative or status quo in his portrayal of Jesus Christ, his desire for racial and ethnic inclusion, and his resistance to the First World War. In doing so, Debs reframed the discussion to focus a new light on the subject of his interest: the working people of the United States. This paper describes the theory of discursive resistance and suggests its use as a tactic for leaders wishing to alter entrenched perceptions, thereby laying the groundwork for change.
\end{abstract}

Keywords: servant-leadership, narrative, discourse, discursive resistance, socialism, framing, Eugene V. Debs

\section{INTRODUCTION}

American Socialist Eugene V. Debs (1855-1926) provides a case study for how a servant-leader might use discursive resistance as a tactic. Robert Greenleaf (1977 [2002]) introduced the idea of the servant-leader in the modern organization in his foundational essay, 'The servant as leader.' Others broadened the scope of servantleadership. For example, Spears and SanFacon (2008, p. 4) wrote, 'At its core, servant-leadership is a long-term, transformational approach to life and work - a way of being - that has great potential for creating positive, non-violent change throughout our society and the world.' This paper will argue that Debs represents this latter conceptualization of servant-leadership and that discursive resistance was central to it.

Discursive resistance is a poststructuralist tactic and this paper looks at the words of Eugene V. Debs through a poststructuralist lens. Poststructuralism relies on the belief that difference is a defining element in our analysis of discourse, power, and norms (Somekh and Lewin 2005, p. 313). In this case, poststructuralism may be defined as the acceptance that 'language is the place where actual and possible forms of social organization ... are defined and contested' (Weedon 1997, p. 21). Foucault (1981) stated that discourse is not only an 'effect' of power, but that it may also be applied as an instrument of power (ibid., p. 101). In order to implement change, a discourse must be in 'circulation' (Weedon 1997, p. 107). According to Kershaw (2006, p. 9), 'A number of productive effects are created by disrupting the narratives of subjectivity and the gendered assumptions operating at the leadership level.' Debs's approach is evidence that challenging the status quo through discursive resistance works. Foucault (1981) suggested that although discourse can reinforce power, it 'also undermines and exposes it, renders it fragile and makes it possible to thwart it' (p. 101). One advantage 
of using both leadership scholarship and poststructuralism is the acceptance of multiple forms of analysis and multiple schools of thought.

Discursive resistance is a tactic that allows a leader to capitalize on the foundational beliefs of a culture or organization that form the basis for the prevailing narrative the leader seeks to contest. The leader's alternative narrative may be utilized to challenge and perhaps defeat the prevailing discourse by exposing its contradictions and demonstrating that the new alternative discourse is really more consistent with the foundational beliefs of the culture or organization the leader is operating within. Without rejecting Americanism, Debs was able to resist and reframe many of the era's contemporary beliefs by presenting a different interpretation or understanding of what Americans already thought or believed (Darsey 1997, p. 112). Through the paradigm of Marxist theory, Debs countered prevailing attitudes toward class, equality, income distribution, liberty, and Christianity as a 'fierce fighter for social justice' (Ginger 2007, p. xv). Biographer Nick Salvatore (1982, p. 343) noted that 'to many Americans he [Debs] symbolized his generation's protest against industrial capitalism.' Debs was a servant of the people and an agitator for change. Historian Ray Ginger (2007, p. 459) wrote of Debs, 'He had come to believe that devotion to the oppressed must be shown by resistance to the oppressors.' Greenleaf (1996) defined the charge of the servant-leader by explaining that servant-leaders use actions and resistance to 'move a society forward' (p. 127). Greenleaf added, 'The opportunity for one who wants to be a constructive building influence, to leave the world a little better if one had not tried, is to make one's contribution to the blend, the meld' (ibid., p. 127).

The influence of poststructuralists allows us the privilege of focusing directly on the language employed by Debs to better understand how his writings and speeches impacted the status quo and the situation that people faced. Debs's vision for America was progressive. In many ways, Debs advocated for an America in concert with Greenleaf's (1977 [2002], p. 27) idea of helping others to 'become healthier, wiser, freer, more autonomous, more likely themselves to become servants.' Certainly, Debs fit Greenleaf's requirement that a great leader be driven by empathy (ibid., p. 34). Debs (1911) attributed much of his influence to 'the passionate sympathy' he felt for the working class; he stated, 'I felt their suffering because I was of them and I began to speak and write for them for the same reason' (p. 2). As a leader, Debs channeled empathy using critical communication to resist the dominant ideas of the day.

\section{INSTITUTIONAL RESISTANCE TO CHANGE}

For resistance to be present, there must be a prevailing narrative or a status quo. I will explore how Debs provided servant-led resistance to the mainline attitudes and biases of his day later, but first, it is important to understand why this resistance is necessary. In other words, why is open discourse not enough to change a prevailing narrative? Debs had to counter an existing narrative; that is but one step toward leading as a servant toward change. Senge (1990, p. 88) noted that norms are 'entrenched because the distribution of authority and control are entrenched.' Senge's dynamic is important to understand because it indicates that change may require significant work.

Institutions do not stand idly by while a narrative or a belief system is challenged. Douglas (1986) provided us the perspective of observing through the lens of what she called the thinking organization. Douglas's thesis was that institutions think at the most basic and complex levels and that an individual's 'cognitive process depends on social institutions' (ibid., p. 45). This idea implies that what we think has a great deal to do with the institutions in which we participate. When industrialist Andrew 
Carnegie (1985, p. 527) accused Socialists of 'attacking the foundation upon which civilization itself rests,' he classified the Socialist as a radical. Later, Carnegie used the term 'industrious worker' to represent the capitalist, and 'incompetent and lazy fellow' to represent the primitive communist (ibid., p. 527). Note the similarity between Carnegie's statements and those made by present-day political blogger John Hawkins (2011, para. 2) describing the Occupy Wall Street movement:

Best I can tell, the idea seems to be that a bunch of over-educated, under-motivated leftie airheads are going to camp out in New York and occasionally block traffic to keep people who are working from getting home until America becomes the Soviet Union circa 1970.

Classifications impact our perceptions and create a collective memory. As an example, historians regularly referred to African-Americans as 'aliens' in history books throughout the late nineteenth and early twentieth centuries. Harvard University professor Arthur Schlesinger (1929) titled a chapter on African-Americans 'The alien peoples' in one of his prominent texts (p. 331). This type of action serves to help institutions remember the potentially false history they have created while forgetting 'experiences incompatible' with their own prevailing ideas (Douglas 1986, p. 112). Durkheim's doctrine of the sacred holds that an organization's response to attack is typically emotional and that it uses sacred words and names to arouse these emotions (ibid., p. 113). Douglas observed, 'Entrenched in nature, the sacred flashes out from salient points to defend all classifications and theories that uphold the institutions' (ibid., p. 113). These classifications also make it difficult for the individual or subgroup to challenge the current authority. Institutions remember details that support the status quo and easily forget challenges (ibid., p. 70). This knowledge suggests that real change requires tactics that will overcome the organization's public memory and foundation.

\section{RESISTANCE THROUGH DISCOURSE}

The use of narrative is a powerful tool available to leaders. According to Gardner (2011, p. 33), 'Leaders achieve their effectiveness through the stories they relate.' Debs's utilization of powerful narratives counter to those of the prevailing business elite helped build a base for his more progressive view of America. Gardner (2011, p. 12) also noted, 'It is important that a leader be a good storyteller but equally crucial that the leader embody that story in his or her life.' Discursive resistance requires more than simple words for change and Debs provided the example Gardner alluded to. Throughout his life as a leader, Debs was frequently jailed and harassed for promoting his narrative. A clear example of this embodiment was his jailing in response to his opposition to the First World War. Freeberg (2008, p. 320) noted that because Debs was willing to spend time in jail, more Americans listened to what he had to say. Servant-leadership scholar Boyd (2009, p. 29) suggested that an act of defiance can also instill hope in a people. Debs (1906, para. 15) suggested that if he employed a strategy of patience and honest communication, his cause would ultimately prove successful.

Moreover, Debs (1970e, p. 188) did not support violence as the proper method of resistance against the capitalist system. Instead, he called on workers to come together as a group. His ideal is consistent with the model of discursive resistance. Weedon (1997) noted that Foucault called this tactic reverse discourse; Weedon stated, 'Reverse discourse enables the subjected subject of a discourse to speak in her own right' (p. 106). St. Pierre (2000, p. 486) stated:

Even though discourse is productive and works in a very material way through social institutions to construct realities that control both the actions and bodies of people, it can be contested. 
Foucault's theory of discourse illustrates that shifts in historical thought do occur when people think of different things to say; therefore, resistance to discourses of domination is possible.

Throughout his public life, Debs used different subjective positions to describe alternative views of equality. For example, Debs $(1914$, p. 1$)$ interpreted Christ as the champion of the poor.

\subsection{From a Protestant work ethic to an imitation of Christ}

Throughout Debs' lifetime, power in American society resided in the persona of the American capitalist as identified by Weber (1958 [1976], p. 176):

A specifically bourgeois economic ethic had grown up. With the consciousness of standing in the fullness of God's grace and being visibly blessed by Him, the bourgeois business man, as long as he remained within the bounds of formal correctness, as long as his moral conduct was spotless and the use to which he put his wealth was not objectionable, could follow his pecuniary interests as he would and feel that he was fulfilling a duty in doing so.

According to Weber, the capitalist was provided with workers who understood that their work was 'willed by God' (ibid., p. 177). Perhaps most importantly, this idea convinced the capitalist 'that the unequal distribution of the goods of this world was a special dispensation of Divine Providence, which in these differences, as in particular grace, pursued secret ends unknown to men' (ibid., p. 177).

Weber (1958, p. 53) observed that, through American style Capitalism, 'Man is dominated by the making of money, by acquisition as the ultimate purpose of his life.' In this narrative, self-interest prevailed. Sumner (1985, p. 513) promoted the idea that 'a free man in a free democracy has no duty whatever toward other men of the same rank and standing, except respect, courtesy and good will.'

The prevailing narrative of the time suggested that equality of opportunity trumped equality of condition. Sumner (1985, p. 516) continued, 'We owe it to each other to guarantee rights. Rights do not pertain to results, but only to chances.' Carnegie (1985, p. 525) had his own ideas regarding wealth; he noted, 'The contrast between the palace of the millionaire and the cottage of the laborer with us to-day measures the change which has come with civilization. This change, however, is not to be deplored, but welcomed as highly beneficial.' Carnegie promoted the idea that the millionaire was in effect the 'trustee of the poor' (ibid., p. 529). This belief was necessary because the dominant discourse stigmatized the poor as lazy and prevailed upon society to ignore those deemed to lack drive or a spirited work ethic. Carnegie asserted that providing assistance to the 'unworthy' poor was irresponsible: 'In alms-giving more injury is probably done by rewarding vice than by relieving virtue' (ibid., p. 529).

Debs (1914) sought to reframe the discourse regarding religion and economics. Debs appears to have leaned toward a belief system championed by men like Reverend Herbert G. Leonard, who, as Carter (2010, p. 332) reported, supported the notion that 'Moses, not Marx, was the progenitor of socialism, and furthermore that the churches had betrayed Christ by neglecting the downtrodden.' Referring to the servant-leader's responsibility to the people, Greenleaf (1977 [2002], p. 27) asked, 'Do they, while being served, become healthier, wiser, freer, more autonomous, more likely themselves to become servants? And [sic], what is the effect on the least privileged in society? Will they benefit, or, at least, not be further deprived?' Debs maintained a focus on the least privileged as he presented an alternative view of Christ's support for the downtrodden. 
Debs (1898) applied discursive resistance as he challenged the prevailing discourse of the Protestant work ethic. He wrote, 'Wealth, instead of blessing the race, has been the means of enslaving it. The few have come in possession of all, and the many have been reduced to the extremity of living by permission' (ibid., para. 1). In this example of discursive resistance, Debs employed Jesus Christ as an ally. As he attacked the prevailing narrative, Debs utilized the Christian foundation that the dominant discourse of the day had been built on. Debs (1914) wrote of a Christ who would combat the capitalist notion that unequal distribution of wealth was part of God's divine plan by re-framing Christ as a revolutionary. Debs (ibid., p. 1) explained that Christ 'has persisted in spite of two thousand years of theological emasculation to destroy his revolutionary personality, and is today the greatest moral force in the world.' Debs focused on the difference between the dominant narrative and his resistance, accusing the ruling class of offering up Christ as 'the divinely commissioned conservator of the peace and soother of the oppressed, instead of the master proletarian revolutionist and sower of the social whirlwind' (ibid., p. 1).

Even early in Debs' career, Salvatore (1982, p. 64) noted that Debs had the ability to convert the Protestantism of the day to promote his new message, because 'Debs discovered that his culture's Protestant religious imagery was particularly suited to both his emerging new message and to his public personality.' Debs found that he was able to use Christianity unapologetically and even harshly to support his claims, and this tactic augmented his 'charismatic appeal with audiences' (ibid., p. 64). Gordon (1994, p. xvii) asserted, 'Foucault wanted to generate doubt and discomfort, and help stimulate a wider process of reflection and action leading to other and more tolerable forms of thinking and acting.' As is consistent with Foucault's approach, Debs excelled in generating discomfort with the status quo. At the same time, he accepted the Christian foundation of American society, simply reframing the discussion.

Debs (1914) framed the battle between the working class and the capitalists as a clear-cut Christian example of conflict between good and evil, but in Debs's narrative, it was the capitalists who were dead wrong. He noted, 'Pure communism was the economic and social gospel preached by Jesus Christ' (ibid., p. 2). Debs also wrote of Christ, 'Private property was to his elevated mind and exalted soul a sacrilege and a horror; an insult to God and a crime against man' (ibid., p. 2). Debs attacked the prevailing idea of Divine Providence and replaced it with a vision of Christ dying for the meek - for the working class. Debs wrote that Christ 'had the majesty and poise of a god, the prophetic vision of a seer, the great, loving heart of a woman, and the unaffected innocence and simplicity of a child' (ibid., p. 3). He focused less on the forgiving Jesus and more on the 'martyred Christ of the working class, the inspired evangel of the downtrodden masses, the world's supreme revolutionary leader' (ibid., p. 3). Debs called on the working masses to see Christ as a revolutionary 'inspiration' (ibid., p. 3). He utilized discursive resistance, focusing on a narrative that resisted the dominant thinking that the distribution of wealth was part of God's plan and sought instead to promote the idea that God would view the distribution of wealth as unjust.

Debs saw injustice all around. He was particularly concerned about conditions for the children of the working poor. Debs (1910b, para. 9) made the case for a Christianity that preferred the weak and downtrodden, stating, 'The sweetest, tenderest, most pregnant words uttered by the proletaire of Galilee were: "Suffer little children, and forbid them not, to come unto me; for of such is the kingdom of heaven".' Debs (1904b) indicted those who put down the Pullman Strike as oppressors, claiming that, had Christ been present, he would have supported the strikers, 'Had the Carpenter of Nazareth been 
in Chicago at the time he would have been on the side of the poor, the heavy-laden and sore at heart, and he would have denounced their oppressors' (p. 12).

Debs often framed laborers as the righteous heirs to God's grace, as evidenced through his involvement in the Pullman Strike and his subsequent jailing. Gutman (1966, p. 88) described Debs's empathy, explaining, 'Eugene V. Debs bristled with Christian indignation at human suffering and cannot be understood outside that framework.' Debs used discursive resistance as a servant-leader when, from his jail cell, he challenged the idea that God supported the business class. He claimed that Labor Day 'would stand first in Labor's Millennium, that prophesied era when Christ shall begin his reign on the earth to continue a thousand years' (ibid., p. 88). The use of discursive resistance allowed for an alternative narrative that could not easily be rejected, as it was foundationally accepting of many current values.

\subsection{Inclusion of race, sex, and nationality}

Debs would attack the prevailing ideas on sex, race and nationality in much the same way. The early twentieth century held little promise for black Americans, women, and immigrants. As a group, black Americans had been segregated, disenfranchised, and largely turned into second-class citizens (Dray 2010, pp. 180-282). Dray (ibid., pp. 181-182) noted that many unions excluded blacks from membership and that the idea of 'black inferiority appeared without question.' The Triangle fire of 1909 burned 146 mostly young women who had heard their protests for more 'sanitary conditions' ignored by uncaring management (ibid., p. 271). Meanwhile, immigrants were viewed by publications such as Atlantic Monthly as presenting a very real problem for America's future because of their 'dangerous motives' (as cited in Dray 2010, p. 319). Some union groups such as the American Federation of Labor were prompted to consider denying membership to immigrants (ibid., p. 319). Debs personified the servant-leader through his commitment to building a united, as opposed to a divisive, community. Greenleaf (1977 [2002], p. 341) noted, 'Servant-leaders differ from other persons of goodwill because they act on what they believe. Consequently, they "know experimentally" that there is a sustaining spirit when they venture and risk.' Kouzes and Posner (2002, p. 330) observed, 'If others know we genuinely care about them, they're more likely to care about us. This is how we bridge cultural divides.' Debs acted, utilizing the tool of discursive resistance, to bridge these cultural divides when confronted by racial-, gender-, or nation-based injustice.

Debs was atypically firm in his support for racial equality. Fellow socialist W.E.B. Du Bois (1913) criticized many in the Socialist movement for inaction; he asserted that Socialists ignored the plight of African-Americans in assuming 'that the whole battle of Socialism is coming by a kind of evolution in which active individual effort on their part is hardly necessary' (pp. 138-139).

Debs could have easily sidestepped the question of race. However, in his essay The Negro in the Class Struggle, Debs (1970d) made it clear, some 10 years before Du Bois' remarks, that he would resist the current discourse of separation and superiority. He wrote (ibid., p. 87), 'The history of the Negro in the United States is a history of crime without parallel.' Debs responded to the injustice of a racist America, stating, 'My heart goes to the Negro and I make no apology to any white man for it' (ibid., p. 89). Debs confronted Americans for supporting racism and wrote of the outrage the prejudiced outlook evoked in him: 'When I see the poor, brutalized, outraged black victim, I feel a burning sense of guilt for his intellectual poverty and moral 
debasement that makes me blush for the unspeakable crimes committed by my own race' (ibid., p. 89).

Refusing to ignore the Negro problem, Debs (1970c) demonstrated resistance in discourse when he challenged prevailing ideas about separation. He declared that the Socialist Party must come together, because Socialism 'is based upon the modern class struggle in which workers of all countries, regardless of race, nationality, creed, or sex, are called upon to unite against the capitalist class, their common exploiter and oppressor' (ibid., p. 93).

Responding to the popular belief that whites and Negroes were incapable of living together and needed to be separated through Jim Crow laws and other forms of segregation, Debs (ibid., p. 95) reframed the problem: 'The fact is that it is impossible for the Anglo-Saxon and the African to live on unequal terms.' For Debs, racism existed because of economic inequality. He explained (ibid., p. 2),

What the Negro wants is not charity but industrial freedom and then he will attend to his own education. There is no 'Negro problem,' apart from the general labor problem. The Negro is no one whit worse off than thousands of white slaves who throng the same labor market to sell their labor-power to the same industrial masters. The workers, white and black, want land and mines and factories and machinery, and they are organizing to put themselves in possession of these means of production and then they will be their own employers, they will get all they produce and the problem will be solved.

Debs attempted to move the discussion away from difference and focus on the reality that workers were in a similar economic position regardless of color. Debs built on the American foundational belief in equality while rejecting the dominant belief that it could provided on separate terms.

Debs (1970c) asked the reader to change perspectives and think about how he or she would feel in the place of the African-American when considering the idea of separate but equal. "Of course the Negro will "not be satisfied with equality with reservation,", he affirmed, adding, 'Why should he be? Would you?' (ibid., p. 94). In this way, the issue is reframed when we look at everyone as an equal member of human race. When the Committee on Immigration recommended excluding certain immigrant races from membership of the party, Debs (1910a) responded by demanding that the party take an inclusive approach to membership. He argued that the idea that

certain races are to be excluded because of tactical expediency would be entirely consistent in a bourgeois convention of self-seekers, but should have no place in a proletariat gathering under the auspices of an international movement that is calling on the oppressed and exploited workers of all the world to unite for their emancipation. (Ibid., para. 1)

Debs (1970e) stated that the Socialist movement had to be inclusive, not exclusive. He called for inclusion regardless of racial or ethnic origin and, somewhat radically for the time, regardless of sex, noting, 'In this work, to be successfully accomplished, woman must have an equal part with man' (ibid., p. 172). Debs wrote that the revolutionary movement stood for "the absolute equality of the sexes and when this fact is fully realized and the workingwoman takes her place side by side with the workingman all along the battlefront the great struggle will soon be crowned with victory' (ibid., p. 172). Notice that Debs presented gender equality as a 'fact' that had only to be realized. His work is marked by a consistent reframing of a world view.

Servant-leadership scholar Kim (2004, p. 203) wrote, 'Foresight is about being able to perceive the significance and nature of events before they have occurred.' Debs (1904a) was able to envision a future in which the working class eventually would 
"unite and act together upon a common basis of equality in spite of "the world, the flesh, and the devil"' (p. 2).

\subsection{Opposition to the First World War and support of liberty and free speech}

Foucault (1981, p.102) noted that even in a liberal democracy, 'there can exist different and even contradictory discourses within the same strategy.' This conflict might explain why during a war purported to make the world safe for democracy, civil liberties were compromised. Rather than embracing the ideals of free speech, President Wilson 'equated dissent with treason, blurring the distinction between German spies and American dissenters' (Freeberg 2008, p. 53). The press was little more concerned; as Freeberg (ibid., p. 53) noted, 'In Debs' hometown, the local paper wished aloud that all the anti-war socialists could either be swept into a Prussian prison camp or boiled in oil.' Institutional pressure culminated in the passage of the 1918 Sedition Act. According to Carman and Syrett (1952, p. 428), 'The Bureau of Investigation made illegal arrests, confiscated private papers, raided newspaper offices, destroyed private property, and held prisoners without bail.' People were sent to jail, not for overt acts, but for opinions uttered 'in the heat of private altercation, on a railroad train, in a hotel lobby or at the battleground of disputation, a boarding house table' (ibid., p. 429). The primary targets of these assaults on liberty were left-leaning liberal groups and their members (ibid., p. 429).

Ferch (2004, p. 226) described the idea of the servant-leader as being 'rooted in the far-reaching ideal that people have inherent worth.' Servant-leaders also strive to involve the whole community, not just the elites, through 'the sharing of power in decision making' (Spears 1998, p. 3). Debs fought for the worth of the working man who would bear the brunt of the fighting. Debs (1970b, p. 246) voiced anger toward the wealthy, whom he accused of becoming patriots so that they might benefit from the war. He said aloud that the idea that America was a free society was not believable, stating, 'This is too much even for a joke' (ibid., p. 245). Debs was concerned that the people had no voice: 'If the war is right let it be declared by the people' (ibid., p. 255). In opposing American involvement in the First World War, Debs used discursive resistance to expose the contradictions of federal policy. He deliberately reframed the discussion by exposing the contradictions in the government's language. At Canton, Debs reminded the public that America had recently enjoyed very good relations with the Kaiser (ibid., pp. 242-244). He pointed out that originally it was not the Democrats or Republicans who opposed Germany; it was the socialists, as they were opposed to Prussian militarism now and always (ibid., p. 242). He said, 'Between us there is no truce - no compromise' (ibid., p. 242). That statement reframed the argument as one about civil liberties rather than about questioning the patriotism of the socialists.

Debs utilized discursive resistance as he built on the American foundation of rights and freedom and rejected the prevailing belief that suspending those very freedoms was the best way to preserve them. According to Brommel (1966, pp. 146-147), Debs believed that it was the capitalist class who made war, but it was the working class who paid the price in lives lost senselessly on the battlefield. In other words, this was no war to protect democracy. Debs (1970b) argued that the war and its supporters were the real threat to democracy, asserting, 'Every solitary one of these aristocratic conspirators and would-be murderers claims to be an arch-patriot' (p. 248). He disagreed emphatically: 'What humbug! What rot! What false pretense! These 
autocrats, these tyrants, these red-handed robbers and murderers ... they are the disloyalists and traitors' (ibid., p. 248). Consistently providing an alternative discourse through his reframing of the situation, Debs provided Americans with the resistance necessary to challenge the 1918 Sedition Act (Ginger 2007, pp. 356-369). For Debs (1970b), the people needed to have the real voice in the declaration of war and the forging of peace; he said, 'It is the ruling class that does both. They alone declare war and they alone make peace' (p. 255).

Debs (1970b) called on those present at an anti-war rally at Canton, Ohio, to be true to what he believed they knew in their hearts to be right. He called out, 'Be true to yourself and you cannot be a traitor to any good cause on earth' (ibid., p. 272). As a result of the Canton speech, Debs was brought to trial and convicted on charges of sedition. Knowing this conviction was all but guaranteed; Debs (1970a) addressed the jury, attacking the contradictions present in the government's case, noting that nearly every war in which America had been engaged had been opposed by elements of American society (ibid., p. 279). The question was not whether the war was right or wrong, but rather whether Americans should have the right to question the underlying motives. Discursive resistance requires that we find a common basic belief; Debs appealed to the American idea of basic rights supported by the Constitution. He reminded Americans that the First Amendment to the Constitution protected the freedom of speech and the right to peaceably assemble in public (ibid., p. 280). He emphasized, 'That is perfectly plain English. It can be understood by a child. I believe the revolutionary fathers meant just what is stated' (ibid., p. 280).

Debs provided an anti-war vision that others, notably Martin Luther King, Jr, used as a foundation for their own work. As Kazen (2009, p. 987) noted, 'Although King was skilled at pragmatic maneuvers, his vision for a new America was closer to the dream of Eugene Debs than to a racially tolerant version of Cold War liberalism.' Historian Earnest Freeberg (2008) suggested that the Debs speech, trial, conviction, and later amnesty campaign had lasting implications for America as a nation and a people. Freeberg explained that Debs's exposure of the governmental contradictions and the amnesty campaign that exposure would inspire 'forced the government to moderate its program of repression and surveillance' (ibid., p. 6). Finally, Debs's actions 'pioneered a form of free speech politics that has played a crucial role in American society ever since' (ibid., p. 6).

\section{CONCLUSION}

The three topics analysed here - income inequality, equal rights, and freedom of speech are still important issues today. It might benefit us to review Debs's approach to these issues as they might reinvigorate the debate. Debs's intentions were in agreement with the promise hinted at in Greenleaf's (1977 [2002]) work: that a true servant seeks to improve the lives of others. Debs $(1911$, p. 2) attributed his success as an orator to this intention, insisting, 'Slavery never inspired an immortal thought or utterance. Selfishness is dead to every art. The love of truth and the passion to serve it light every torch of real eloquence.' The value of Debs as a leader may be judged by his impact on others and his ability to change the conversation and inspire others through the tactic of discursive resistance. Burns (2003, p. 240) clarified this measurement, writing that as 'individuals draw together' to change conditions, 'their collective efficacy unites them into a transforming force' that may eclipse the role of the leader. The study of history is more than a recitation of facts. Utilized correctly, the past can open our eyes to a better 
future. Poststructuralism allows us to utilize the idea of resisting a dominant discourse, transplant it from a feminist and gender rights based tradition and apply it to another situation. Coming from a tradition that deals extensively with historical oppression, it is not a stretch to apply these ideas to workers' rights or other areas of particular interest to Debs. At the same time, we may incorporate other approaches, such as Gardner's ideas on narrative and the importance of embodying that in action. This is an advantage of leadership studies' multidisciplinary approach. Looking at Debs's words through a poststructural lens allows us the privilege of another perspective on an important progressive American leader. This lens clarifies how leaders might utilize the tool of discursive resistance to change a dominant and oppressive narrative. The willingness to be self-sacrificing is integral to the liberal tradition of servant-leadership and thus runs as an alternative to more conservative protestant-work-ethic-influenced strains of leadership. Weedon (1997, p. 108) wrote, 'It may well take extreme and brave actions on the part of the agents of challenge to achieve even small shifts in the balance of power.' Such actions allow 'marginal discourses' to 'increase their social power' (ibid., p. 108). Many of the ideas Debs championed in his day were considered radical. Yet many of these same ideas have become foundational to our American experience, including civil rights, unemployment insurance, and social security, while others, such as opposition to foreign wars, remain a resistant undercurrent. Debs's tactic of discursive resistance is a useful tool for servant-leaders wishing to agitate for meaningful change.

\section{REFERENCES}

Boyd, J. (2009). A Servant Leader's Journey: Lessons from Life. Mahwah, NJ: Paulist Press.

Brommel, B. (1966). The pacifist speechmaking of Eugene V. Debs. Quarterly Journal of Speech, 52(2), 146-154.

Burns, J. (2003). Transforming Leadership. New York, NY: Atlantic Monthly Press.

Carman, H. and Syrett, H. (1952). A History of the American People: Volume II. New York, NY: Alfred A. Knopf.

Carnegie, A. (1985). It is a waste of time to criticize the inevitable. In G. Baker and A. Mason (eds), Free Government in the Making: Readings in American Political Thought. New York, NY: Oxford University Press, pp. 525-528.

Carter, H. (2010). Scab ministers, striking saints: Christianity and class conflict in 1894 Chicago. American Nineteenth Century History, 11(3), 321-349.

Darsey, J. (1997). Prophetic Tradition and Radical Rhetoric in America. New York, NY: New York University Press.

Debs, E. (1898). The martyred apostles of labor. The New Time, February, pp. 79-82. Retrieved from http://www.marxists.org/archive/debs/works/1898/martyred.htm.

Debs, E. (1904a). Debs on the color question. Appeal to Reason, no. 396, July 4, p. 2.

Debs, E. (1904b). The federal government and the Pullman strike: Eugene V. Debs' reply to Grover Cleveland's magazine article. Appeal to Reason, whole no. 456, August 27, pp. 1-2.

Debs, E. (1906). You railroad men. Pamphlet, Eugene V. Debs Internet Archive. Retrieved from http://www.marxists.org/archive/debs/index.htm.

Debs, E. (1910a). Letter to Brewer. International Socialist Review, XI(1), July. Retrieved from http://www.marxists.org/archive/debs/works/1910/immigration.htm.

Debs, E. (1910b). The little lords of love. Progressive Woman, December. Eugene V. Debs Internet Archive. Retrieved from http://www.marxists.org/archive/debs/index.htm.

Debs, E. (1911). The secret of efficient expression. The Coming Nation, July 8, pp. 1-2.

Debs, E. (1914). Jesus, the supreme leader. Progressive Woman, March, pp. 1-3. Eugene V. Debs Internet Archive. Retrieved from http://www.marxists.org/archive/debs/index.htm.

Debs, E. (1970a). Address to the jury. February, 1903. In J. Tussey (ed.), Eugene V. Debs Speaks. New York, NY: Pathfinder, pp. 275-281. (Originally published 1918.) 
118 Leadership and the Humanities, Vol. 2 No. 2

Debs, E. (1970b). The Canton, Ohio, speech. June 16, 1918. In J. Tussey (ed.), Eugene V. Debs Speaks. New York, NY: Pathfinder, pp. 239-272.

Debs, E. (1970c). The Negro and his nemesis. In J. Tussey (ed.), Eugene V. Debs Speaks. New York, NY: Pathfinder, pp. 90-99. (Originally published in International Socialist Review, January, 1904.)

Debs, E. (1970d). The Negro in the class struggle. In J. Tussey (ed.), Eugene V. Debs Speaks. New York, NY: Pathfinder, pp. 85-90. (Originally published in International Socialist Review, February, 1903.)

Debs, E. (1970e). Working class politics. In J. Tussey (ed.), Eugene V. Debs Speaks. New York, NY: Pathfinder, pp. 169-172. (Originally published in International Socialist Review, November, 1910.)

Douglas, M. (1986). How Institutions Think. Syracuse, NY: Syracuse University Press.

Dray, P. (2010). There is Power in a Union: The Epic Story of Labor in America. New York, NY: Doubleday.

Du Bois, W. (1913). Socialism and the Negro problem. The New Review, 1(1), February 13, $138-141$.

Ferch, S. (2004). Servant-leadership, forgiveness, and social justice. In L. Spears and M. Lawrence (eds), Practicing Servant-Leadership: Succeeding Through Trust, Bravery, and Forgiveness. San Francisco, CA: Jossey-Bass, pp. 225-239.

Foucault, M. (1981). The History of Sexuality: Volume One. An Introduction. New York, NY: Pantheon.

Freeberg, E. (2008). Democracy's Prisoner: Eugene V. Debs, the Great War, and the Right to Dissent. Cambridge, MA: Harvard University Press.

Gardner, H. (2011). Leading Minds: An Anatomy of Leadership. New York, NY: Basic Books.

Ginger, R. (2007). The Bending Cross: A Biography of Eugene V. Debs. Chicago, IL: Haymarket.

Gordon, C. (1994). Introduction. In J. Faubion (ed.), Michel Foucault: Power. New York, NY: The New Press, pp. xi-xli.

Greenleaf, R. (1977 [2002]). Servant Leadership: A Journey into the Nature of Legitimate Power and Greatness. New York, NY: Paulist Press.

Greenleaf, R. (1996). On Becoming a Servant Leader. San Francisco, CA: Jossey-Bass.

Gutman, H. (1966). Protestantism and the American labor movement: the Christian Spirit in the gilded age. The American Historical Review, 72(1), 74-101.

Hawkins, J. (2011). Occupy Wall Street is like a parody of a protest. Retrieved from http://www. huffingtonpost.com/john-hawkins/occupy-wall-street-parody_b_995417.html.

Kazen, M. (2009). AHR forum: Martin Luther King, Jr. and the meaning of the 1960s. American Historical Review, October, 980-989.

Kershaw, N. (2006). Women primary principals: leadership between the flags. In P.L. Jeffery (ed.), AARE 2006: Conference Papers, Abstracts and Symposia. Coldstream, Victoria: Australian Association for Research in Education, pp. 1-11.

Kim, D. (2004). Foresight as the central ethic of leadership. In L. Spears and M. Lawrence (eds), Practicing Servant-Leadership: Succeeding through Trust, Bravery, and Forgiveness. San Francisco, CA: Jossey-Bass, pp. 201-224.

Kouzes, J. and Posner, B. (2002). The Leadership Challenge. San Francisco, CA: Jossey-Bass.

Salvatore, N. (1982). Eugene V. Debs: Citizen and Socialist. Urbana, IL: University of Illinois Press.

Schlesinger, A. (1929). Political and Social History of the United States: 1829-1925. New York: Macmillan.

Senge, P. (1990). The Fifth Discipline: The Art and Practice of the Learning Organization. New York, NY: Currency.

Somekh, B. and Lewin, C. (2005). Research Methods in the Social Sciences. Thousand Oaks, CA: Sage.

Spears, L. (1998). Introduction. In L. Spears (ed.), Insights on Leadership: Service, Stewardship, Spirit, and Servant Leadership. New York, NY: John Wiley, pp. 1-12. 
Spears, L. and SanFacon, G. (2008). Holistic Servant-Leadership. Indianapolis, IN: The Spears Center for Servant-Leadership.

St. Pierre, E. (2000). Poststructural feminism in education: an overview. International Journal of Qualitative Studies in Education, 13(5), 477-515.

Sumner, W. (1985). A free man in a free democracy has no duty whatever toward other men of the same rank and standing. In G. Baker and A. Mason (eds), Free Government in the Making: Readings in American Political Thought. New York, NY: Oxford University Press, pp. 510-517.

Weber, M. (1958 [1976]). The Protestant Ethic and the Spirit of Capitalism. New York, NY: Charles Scribner's Sons.

Weedon, C. (1997). Feminist Practice and Poststructuralist Theory. Malden, MA: Blackwell. 